\title{
In Vitro Enhancement of Ciprofloxacin, Tobramycin, and Nystatin Activity by Irradiated Aqueous Garlic Extract Against Multidrug Resistant Pathogens Causing Otitis Media
}

\author{
Eman A. Mustafa ${ }^{1}$, Hanady G. Nada ${ }^{1}$, Hala N. Elhifnawi ${ }^{1}$, Abd El Gawad Hashem ${ }^{2}$, and Rania A. Khattab ${ }^{2}$ \\ (1) Drug Radiation Research Department, Biotechnology Section, National Center for Radiation Research and Technology, Egyptian \\ Atomic Energy Authority (EAEA), Cairo, Egypt. \\ (2) Department of Microbiology and Immunology, Faculty of Pharmacy, Cairo University, Kasr Al-Aini, Cairo, Egypt.
}

\begin{tabular}{l} 
ARTICLE INFO \\
\hline Article history: \\
Received: $8^{\text {th }}$ July 2021 \\
Accepted: $8^{\text {th }}$ Sept. 2021 \\
\hline
\end{tabular}

Keywords:

Gamma rays,

otitis media

Pseudomonas aeruginosa

Alcaligenes faecalis,

Aspergillus flavus,

Aspergillus niger,

Penicillium chrysogenum.

\section{ABSTRACT}

Otitis media $(\mathrm{OM})$ is a worldwide major health and economic issue leading to hearing loss, especially in developing countries due to high antibiotic resistance among the causative pathogens. This study aims to isolate, purify and determine the prevalence of MDR microorganisms causing $O M$. This is in addition to estimate in vitro effectiveness of irradiated and un-irradiated aqueous garlic extract (AGE). Finally, the present study aims to evaluate the enhancement of CIP, TOB, and NYS, commonly used in OM treatment, with IAGE against identified MDR bacteria and fungi. In the current investigation, the in vitro data revealed that $O M$ is more prevalent in middle aged adults than in children. OM were predominated by bacterial isolates $(\mathbf{5 9 . 0 \% )}$, followed by fungal isolates (41.0\%), including Pseudomonas aeruginosa (5 isolates), Proteus mirabilis (3 isolates), in addition to Klebsiella pneumoniae, Alcaligenes faecalis, Enterococcus faecalis, Bacillus cereus, Penicillium chrysogenum, Aspergillus flavus, and Aspergillus niger (1 isolate). Irradiated AGE (IAGE) showed nearly the same antimicrobial activity as the un-irradiated AGE. The inhibition activity enhancement was more statistically significant $(P<0.001)$ on combination of IAGE with CIP\NYS than with TOB $(P<0.05)$ and $(P<0.001)$ compared with each alone. Noticeable morphological changes in $P$. aeruginosa and A. flavus were observed by TEM images after the combination of IAGE with CIP/NYS. This study is one of primarily attempts to evaluate the IAGE to be used in future as a natural, safe, sterile, low cost, and available whole additive in therapeutic protocols to overcome MDR problem

\section{INTRODUCTION}

Otitis media $(\mathrm{OM})$ refers to inflammation of the mucosal lining of the middle ear and resulting in a variety of medical conditions with different signs and symptoms, causing discomfort and anxiety across all ages leading to hearing impairment [1]. There has been a significant increase worldwide in the diagnosis of OM during the past two decades. The prevalence of $\mathrm{OM}$ in children is high in the USA, affecting more than 30 million children per year as reported by the United States Department of Health and Human Services[2]. Consequently, the World Health Organization reported $\mathrm{OM}$ as a considerable health problem and called for more detailed epidemiological data [3]. The most common cause of OM is fluid accumulation behind the eardrum because of eustachian tube dysfunction [4]. This leads to the development and accumulation of potentially pathogenic bacteria, fungi, yeasts and viruses in the fluid [5], resulting in recurrent and aggressive reappearance of OM infections. Misuse of antimicrobial agents resulted in the development of multidrug-resistant (MDR) strains, leading to health and economic issues [6].

The search for safe, low cost, eco-friendly alternative healthcare approaches to diminish the problem of OM infections caused by MDR pathogens is crucial and gaining much attention worldwide as an alternative strategy against antibiotic resistance[7]. In the era of antibiotic resistance, natural herbal products may provide appropriate and acceptable alternative solutions 
in terms of their broad-spectrum antimicrobial activity, safety, cost effectiveness and availability, when compared to their synthetic counterparts[7-9]

Garlic (Allium sativum) is a herb belonging to the Liliaceae family [10]. Garlic bulbs have been used from ancient centuries in folk medicine as protective and curative agent[11]. Garlic exerts a substantial variety of biological activities; antimicrobial [12], antithrombotic [13], anticancer [14], and antioxidant [15] agent as well as an enhancer of the immune system [16]. The organosulfur compounds are considered the bioactive antimicrobial compounds in garlic [17]. Allicin is the main bioactive compound that is only found in freshly crashed garlic bulbs[7]. Several antimicrobial mechanisms, extracellular and intracellular, are reported regarding the bioactive organosulfur compounds in garlic[18]. Intracellularly, it overlaps with RNA synthesis [9]. This is in addition to the reactivity of thiosulfinates towards thiol groups in the essential enzymes. However, the electron withdrawing effect of O-atom creates an electrophilic sulfur center which reacts actively with thiol groups. Many crucial enzymes such as; alcohol dehydrogenases, acetate kinase, thioredoxin reductase, phophotransacetyl-CoA synthetase, and others in bacteria, fungi, yeasts and viruses are with critically important thiol groups, so they are easily oxidized and inhibited when exposed to allicin $[17,19]$. Furthermore, allicin reacts with glutathione (GSH), low molecular weight cellular thiols, altering the ratio of reduced-GSH to more oxidized state and this causes apoptosis, as confirmed by cytological and genetic assays [19,20]. Extracellularly, allicin is a lipophilic compound and its antimicrobial activity is facilitated by its permeability through its membrane[19]. At the same time, allicin is able to form passage pores in bio-membrane, which probably accounts for its synergy with antibiotics [17].

Gamma radiation is a type of ionizing radiation with a high frequency and very short wavelength that is emitted by unstable radioactive isotopes, such as ${ }^{60} \mathrm{Co}$. The biological impact of gamma radiation is based on its interaction with water to produce free radicals [21]. According to the codex general standard for irradiated food [22] processing and preserving food are limited to high energy photons ( $\gamma$-rays from ${ }^{60} \mathrm{Co}$ )[23]. Therefore, food irradiated at low doses of $\gamma$-irradiation have been approved to be safe and effective cutting-edge technique to extend food products shelf life by inactivating the food-borne pathogens and retarding food spoilages without causing side effects or changing in chemical structure [24,25].

The main objective of this work was to identify the pathogens causing OM infections in our region and evaluate the in vitro antimicrobial effectiveness of the irradiated aqueous garlic extract (IAGE), alone and in combination with the commonly used antimicrobial agents (ciprofloxacin (CIP), tobramycin (TOB), and nystatin (NYS) ) against the same pathogens.

\section{METHODS}

\subsection{Specimen collection and culturing conditions}

A total number of 49 ear swabs were collected from ear discharges from patients at the microbiological laboratory at Nasr City Health Insurance Hospital, Cairo, Egypt. They were cultured on nutrient, blood, and MacConkey agar plates (Oxoid, UK) incubated aerobically for $18-24 \mathrm{hrs}$ at $35 \pm 2^{\circ} \mathrm{C}$. Sabouraud dextrose agar (SDA) plates (Oxoid, UK) with $0.05 \%$ chloramphenicol $(\mathrm{V} / \mathrm{V})$ were also incubated at the same temperature for 5-14 days to culture fungal isolates.

Pure isolates were preserved and stored at $-20^{\circ} \mathrm{C}$ in Luria-Bertani broth containing 20\% glycerol (V/V) for further investigations. Microscopic examination was carried out to determine the bacterial Gram reaction and examine the morphology of the fungal isolates [26].

\subsection{Antimicrobial susceptibility test}

The Kirby-Bauer disk diffusion method was employed to study the antibiogram of the isolates against 10 antibiotics, namely, amoxicillin (AX), cefotaxime (CTX), cefoxitin (FOX), chloramphenicol (C), ciprofloxacin (CIP), gentamicin (CN), ofloxacin (OFX), tobramycin (TOB), tetracycline (TE), and the antifungal, nystatin (NYS) [27], all were products of Oxoid, the UK. The isolates were categorized as susceptible (S), intermediate (I) or resistant (R), based the inhibition zone diameter according to the CLSI guidelines [28]. Experiments were performed in triplicate.

\subsection{Identification of resistant isolates}

All bacterial isolates that showed resistance to three or more antibiotics were categorized as MDR and were identified by matrix-assisted laser desorption/ionizationtime of flight (MALDI-TOF) mass spectrometry using the Vitek MS System (bioMérieux, France) located at Children's Cancer Hospital 57357 in Egypt. Fungal species that showed inhibition zone diameter (IZD) $\leq 13$ 
$\mathrm{mm}$ around the NYS disc were considered resistant, identified by light microscope, and chosen for further investigations.

\subsection{Preparation of AGE}

Aqueous garlic extract (AGE) was prepared as described by Iwalokun et al. [29]. Briefly, $50 \mathrm{~g}$ of the edible portion of fresh garlic bulbs (purchased from local markets in Cairo, Egypt) were chopped and homogenized in $100 \mathrm{~mL}$ of sterile distilled water using a blender. The final AGE was obtained by passing the homogenized solution through $0.25 \mu \mathrm{m}$ sterile bacterial filter (Viro-Max, USA). The filtrate was collected in a sterile glass container and stored at $4^{\circ} \mathrm{C}$ for a maximum of 3 days.

\subsection{Exposure of AGE to gamma irradiation}

Volumes of $50 \mathrm{~mL}$ of the AGE were irradiated at low doses of gamma irradiation; $0.25,0.5,0.75,1.0,2.0$, or $3.0 \mathrm{kGy}$, using a ${ }^{60} \mathrm{Co}$ Gamma cell, 220 irradiation unit (MDS Nordion, Canada) at the National Center for Radiation and Research Technology of the Egyptian Atomic Energy Authority, Cairo, Egypt. The dose rate was $25 \mathrm{~min} / \mathrm{kGy}$ at the time of the experiment. The unirradiated AGE was used as a control. Each test was performed in triplicate.

\subsection{Antimicrobial efficiency}

\subsubsection{Inhibition potency of the irradiated and un- irradiated AGE}

The inhibition potencies of the irradiated AGE at different doses of gamma radiation $(0.25,0.5,0.75,1.0$, 2.0, and $3 \mathrm{kGy}$ ) and the un-irradiated AGE were assessed using the agar well diffusion assay. Both bacterial and fungal growths were adjusted to a 0.5 McFarland standard $\left(1-2 \times 10^{8} \mathrm{cfu} / \mathrm{mL}\right.$ and $10^{5}$ fungal spores $/ \mathrm{mL}$ ), and swabbed over the entire surface of Muller-Hinton agar and SDA plates (Difco, MI, USA), respectively. A sterile cork borer was used to punch 3 or 4 wells of $8 \mathrm{~mm}$ diameter into each plate. Then, $100 \mu \mathrm{L}$ of the irradiated or un-irradiated AGE was added separately to each well, plates were incubated at $35 \pm$ $2^{\circ} \mathrm{C}$ for $24 \mathrm{hrs}$, or 5 days for bacterial and fungal cultures, respectively. Sterile distilled water and chloramphenicol were used as negative and positive controls, respectively. The inhibition zone diameter was measured, and the extraction showing the highest IZD was chosen for further investigations. All experiments were performed in triplicate, and the results were presented as the average of the data.

\subsubsection{Determination of minimum inhibitory concentration (MIC)}

Agar well diffusion assay was used to determine the MIC of IAGE and the antimicrobial agents against the tested strains using the two-fold serial dilution assay. The chosen IAGE was tested at 8 concentrations (500, $250,125,62.5,31.25,15.62,7.81$, and $3.91 \mathrm{mg} / \mathrm{mL}$ ). However, antibiotic concentrations were $(3.0,1.5,0.75$, $0.375,0.1875,0.09,0.046,0.02,0.01$, and 0.005 $\mathrm{mg} / \mathrm{mL}$ ). Additionally, seven concentrations (500, 250, $125,62.5,31.25,15.62$, and $7.81 \mathrm{mg} / \mathrm{mL}$ ) were selected for NYS. The tested antibiotics were obtained from the Egyptian International Pharmaceuticals Industries Co (EIPICO), Egypt. All experiments were performed in triplicate, and the results were presented as the average of the data.

\subsection{Combination of chosen IAGE with CIP, TOB, and NYS against MDR pathogenic species causing $\mathrm{OM}$}

The synergistic effect of IAGE with CIP or TOB and NYS was evaluated by agar well diffusion method as described by Andualem [30]. An amount of $200 \mu \mathrm{L}$ of treatment was added to each well in an agar plate (100 $\mu \mathrm{L}$ of AGE at the MIC $+100 \mu \mathrm{L}$ of CIP, TOP, or NYS at their corresponding MICs). One hundred $\mu \mathrm{L}$ of AGE alone was used as a control. Plates were incubated at 35 $\pm 2^{\circ} \mathrm{C}$ for $24 \mathrm{hrs}$. for bacteria and 5 days for fungi. The IZDs were measured and compared with that of the antibiotics, antifungal agent, and AGE alone.

\subsection{Transmission electron microscopy (TEM)}

Transmission electron microscopy (TEM) (JEOLJEM 1010, JEOL Ltd, Japan) at the Regional Centre for Mycology and Biotechnology ( at Al-Azhar University, Cairo, Egypt) was used to study the ultrastructure of the selected strains before and after treatment with the selected antibiotic alone and in combination with IAGE as described by Lu et al. [31].

\subsection{Statistical analysis}

The mathematical analysis of the data was performed by one-way analysis of variance (ANOVA) (at $P<0.05$ ) for testing the null hypothesis of no difference in IZD [32]. When ANOVA led to denial of the null hypothesis, multiple-range testing was carried out using Duncan's multiple range test (DMRT) [33]. The synergistic effects through increase in IZD [34] were examined and analyzed through SPSS v20 statistical software (IBM Corp, NY, USA). 


\section{RESULTS AND DISCUSSION}

Otitis media $(\mathrm{OM})$ is a chief chronic disease with $2-8$ fold higher prevalence in low and middle-income countries compared to the developed ones [6]. More detailed epidemiological data was called by WHO, regarding the $\mathrm{OM}$ as a causative of hearing loss or weakness globally [3]. Determination of the distribution of OM among 49 outpatients visiting the largest public hospital in Nasr City, Cairo, Egypt and reported in this study, provides an added value to the current research. Data on the patients' age and gender were collected in (Table 1). The number of males suffering from $\mathrm{OM}$ was $38 / 49$ (77.6\%), three times higher than females 11/49 (22.4\%). Additionally, one-quarter of specimens were collected from patients aged 0-20 years, with the remainder from patients aged 21-70 years. These results are in accordance with other studies [4,35-38]. The high prevalence of $\mathrm{OM}$ in the men in the present study could be due to extended contact with environmental pollutants as a result of the outdoor working conditions and low levels of hygiene. Furthermore, the prevalence of OM peaked at 51-60 years old $(10 / 49,20.4 \%)$, followed by the ages $60-71$ and $31-40$ years (both $8 / 49,16.3 \%$ ). For ages 51-60 and 61-70 years, OM may occur as a complication of other disorders, low immunity, poor personal hygiene, and a poor ear-cleaning routine [6]. In this study, OM in children (age 0-10 years) represented only 6/49 (12.2\%) patients, which agreed with Loy et al. [39]. However, other studies $[4,6,35,36]$ have reported that $\mathrm{OM}$ infections were commonly observed in children. This variation may be due to the cultural differences in diverse societies, on the other side, the small sample size in the present study could be a contributing factor for this variation.

Table (1): Distribution of otitis media patients according to their age range and gender

\begin{tabular}{|c|c|c|c|c|c|c|}
\hline \multirow{2}{*}{$\begin{array}{c}\text { Age } \\
\text { range } \\
\text { (years) }\end{array}$} & \multicolumn{2}{|c|}{ Male } & \multicolumn{2}{|c|}{ Female } & \multirow{2}{*}{$\begin{array}{c}\text { Total } \\
\text { No. }\end{array}$} & \multirow{2}{*}{$\% * *$} \\
\hline & No. & $\% *$ & No. & $\% *$ & & \\
\hline $0-10$ & 5 & $13.2 \%$ & 1 & $9.1 \%$ & 6 & 12.24 \\
\hline $11-20$ & 2 & $5.3 \%$ & 4 & $36.4 \%$ & 6 & 12.24 \\
\hline $21-30$ & 1 & $2.6 \%$ & 1 & $9.1 \%$ & 2 & 4.1 \\
\hline $31-40$ & 8 & $21.1 \%$ & - & & 8 & 16.33 \\
\hline $41-50$ & 4 & $10.5 \%$ & 2 & $18.2 \%$ & 6 & 12.24 \\
\hline $51-60$ & 9 & $23.7 \%$ & 1 & $9.1 \%$ & 10 & 20.40 \\
\hline $61-70$ & 6 & $15.8 \%$ & 2 & $18.2 \%$ & 8 & 16.33 \\
\hline $71-80$ & 3 & $7.9 \%$ & - & & 3 & 6.12 \\
\hline Total & 38 & $77.6 \% * *$ & 11 & $22.4 \%$ ** & 49 & $100 \% * *$ \\
\hline
\end{tabular}

$*$ = Percentage was correlated to total number of each sex.

$* *=$ Percentage was correlated to total number of total specimens (49).
Out of 49 ear discharge swabs, 78 microbial isolates were obtained, categorized into $46(59.0 \%)$ bacterial isolates, of which 19 (41.3\%) were Gram-positive and 27 $(58.7 \%)$ Gram-negative. The remaining isolates, $32(41.0 \%)$ were fungal isolates, of which $15(46.9 \%)$ were Aspergillus niger (A. niger), 14 (43.8\%) were Aspergillus flavus (A. flavus), and 3 (9.4\%) were Penicillium chrysogenum ( $P$. chrysogenum). They were confirmed by light microscope as shown in (Fig. 1A-C). The percentage of bacterial and fungal isolates causing OM infections were in agreement with previous results [40], but disagreed with others [6]. This dissimilarity may be due to cultural differences between diverse societies. The high prevalence of Aspergillus spp. (90.6\%) and the low prevalence of $P$. chrysogenum (9.4\%) among the fungal isolates causing $\mathrm{OM}$ were in accordance with other studies [3,4,37]. Ghaly et al. [3] reported that Aspergillus sp. represented $75 \%$ of fungal infections isolated from $\mathrm{OM}$ patients admitted to Otolaryngology Department, Zagazig University Hospital, Sharqia, Egypt. Several factors have been determined for bacterial and fungal ear infections such as swimming, ear picking, headwear, nonsterile oils, steroid usage, malnutrition and immature immunity in children, immunocompromised patient and presence of fungal infection in other part of the body [3].
A.

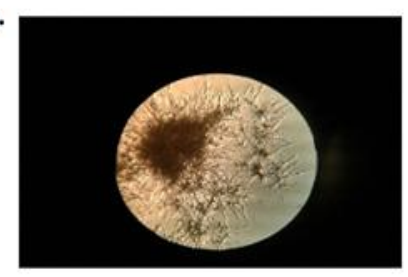

B.

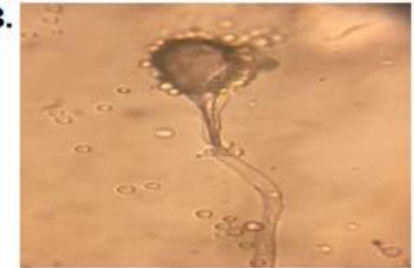

c.

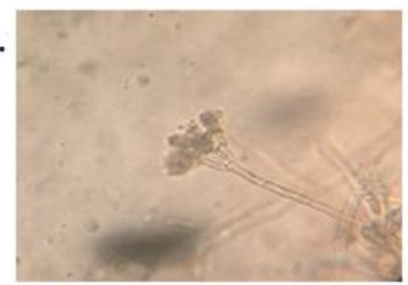

Under microscope
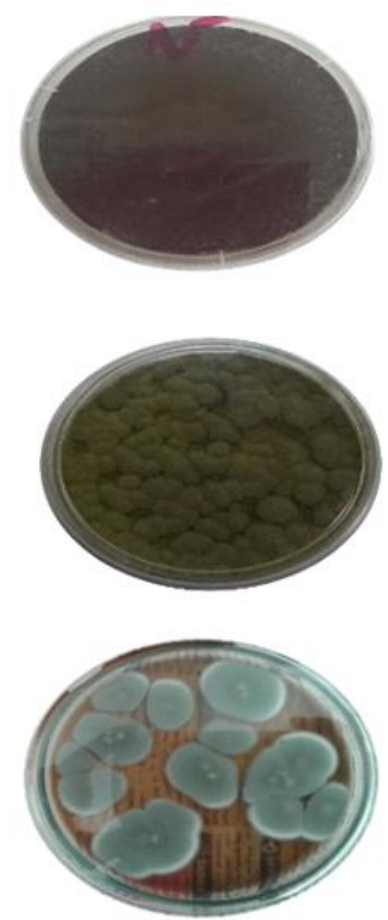

On SDA plate
Fig. (1) Fungal isolates recovered from ear discharges of patients with otitis media (under light microscope and on sabouraud dextrose agar (SDA) plates: A. Aspergillus niger, B. Aspergillus flavus and C. Penicillium chrysogenum 
Emergence of antibiotic resistance is considered a major therapeutic problem $[41,42]$. In the present research, nine antibiotics $(\mathrm{AX}, \mathrm{CTX}, \mathrm{FOX}, \mathrm{TOB}, \mathrm{CN}$, TE, C, CIP, and OFX), belong to five different antibiotic classes namely, penicillins, cephalosporins, aminoglycosides, tetracyclines, chloramphinicols, and quinolones, in addition to a single antifungal agent (NYS) were selected as universally recommended antibiotics by physicians for topical treatments of severe OM infections $[43,44]$. Nystatin is the only licensed antifungal as a powder or as a suspension to treat ear infections. It is used as a first line treatment for ear infections in France and USA since other antifungals are not available in formulation suitable for auricular application [45]. Many previous literatures and researches studied the same antibiotics against bacteria causing OM infections. From USA, Pichichero (2005)[46] declared that pediatricians and general practitioners preferred to use high a dose of amoxicillin/clavulanate, while otolaryngologists in the same country preferred to use cephalosporins for treatment of drug-resistant Streptococcus pneumoniae or Haemophilus influenzae causing OM infections. From Africa, Uddén et al. [38] used CIP, TOB, CN, TE, C, CAZ, CTX, imipenem, meropenem, ceftazidime, cefipime, trimethoprime/sulfamethoxazole, and colistin against the bacterial isolates from chronic suppurrative $\mathrm{OM}$, as a part of project at Ear, Nose and Throat Department at Hospital Josina Machel in Luanda, Angola. Moreover, Abdelshafy (2015)[47] with co-workers, used cefoperazone, cefipime, ceftazidime, pipracillin/tazobactam, meropenem, imipenem, $\mathrm{CN}$, TOB and CIP against MDR P. aeruginosa isolated from chronic suppurative OM in Egypt.

The susceptibility patterns of the 46 bacterial isolates obtained from OM infections in the current study showed high levels of resistance to AX (46\%), FOX (35\%), TE (35\%), and C (17\%) as shown in (Table 2). Meanwhile, OFX, CN, and CIP showed the highest efficiency against the same investigated bacteria, with lowest resistant percentages $0.02,0.07$, and $0.09 \%$, respectively. In an earlier study carried out by Ganesh and Subramaniam [37], it was found that CIP and amikacin were the most effective drugs, followed by AX-clavulanate and ceftazidime for many organisms. However, another study [48] reported high resistance to ampicillin, clotrimazole, cefixime, and CIP, while, sensitivity to Augmentin (AX-clavulanate), OFX, AX, TE, C, and erythromycin was reported. Udden et al. [38] observed higher sensitivity to AX, CTX, CIP, CN, TOB, TE, and $C$ against 823 bacterial isolates obtained from ear discharge and nasopharyngeal samples in Ear, Nose and Throat Department at Hospital Josina Machel, Luanda, Angola. These variations in antibiotic resistant pattern could be attributed to different types of antibiotics prescribed for $\mathrm{OM}$ infections in different geographical regions. Among the 46 bacterial isolates, $12(26.1 \%)$ were considered as multidrug resistant (MDR) pathogens, as they revealed resistance to three or more antibiotics $(\geq 33 \%)$, representing three or more classes, as shown in (Table 2).

Table (2): Antimicrobial susceptibility test for bacterial isolates recovered from patients with otitis media

\begin{tabular}{|c|c|c|c|c|c|c|c|c|c|c|}
\hline A & $\mathrm{AX}$ & CTX & FOX & TOB & $\mathrm{CN}$ & $\mathrm{TE}$ & C & CIP & OFX & \\
\hline $\begin{array}{l}\text { Bacterial } \\
\text { Isolate no. } \\
\text { Number }\end{array}$ & $25 \mu \mathrm{g}$ & $30 \mu \mathrm{g}$ & $30 \mu \mathrm{g}$ & $10 \mu \mathrm{g}$ & $10 \mu \mathrm{g}$ & $30 \mu \mathrm{g}$ & $30 \mu \mathrm{g}$ & $5 \mu \mathrm{g}$ & $\begin{array}{c}5 \\
\mu \mathrm{g}\end{array}$ & ơ \\
\hline 1 & $\mathrm{R}$ & $\mathrm{R}$ & $\mathrm{R}$ & $S$ & $S$ & $\mathrm{~S}$ & $\mathrm{R}$ & $S$ & $S$ & $44 \%$ \\
\hline 2 & $S$ & $S$ & $\mathrm{R}$ & $\mathrm{R}$ & $S$ & $\mathrm{R}$ & $S$ & $S$ & $S$ & $33 \%$ \\
\hline 3 & $S$ & $S$ & $\mathrm{R}$ & $S$ & $S$ & $S$ & $S$ & S & $S$ & $11 \%$ \\
\hline 4 & $S$ & $S$ & $\mathrm{R}$ & $S$ & $S$ & $S$ & $S$ & S & S & $11 \%$ \\
\hline 5 & $S$ & $S$ & $S$ & $S$ & $S$ & $S$ & $S$ & $S$ & $S$ & $0 \%$ \\
\hline 6 & $\mathrm{R}$ & $\mathrm{R}$ & $\mathrm{R}$ & $\mathrm{R}$ & $\mathrm{R}$ & $\mathrm{R}$ & $S$ & $\mathrm{R}$ & $S$ & $78 \%$ \\
\hline 7 & $\mathrm{R}$ & $\mathrm{R}$ & $\mathrm{R}$ & $S$ & $S$ & $\mathrm{R}$ & $S$ & $S$ & $S$ & $44 \%$ \\
\hline 8 & $\mathrm{R}$ & S & $S$ & $S$ & $S$ & $S$ & $S$ & S & S & $11 \%$ \\
\hline 9 & I & $\mathrm{R}$ & $S$ & $S$ & $S$ & $S$ & $S$ & $S$ & $S$ & $11 \%$ \\
\hline 10 & $\mathrm{R}$ & $S$ & $\mathrm{~S}$ & S & $\mathrm{S}$ & $S$ & $\mathrm{R}$ & $S$ & S & $22 \%$ \\
\hline
\end{tabular}




\begin{tabular}{|c|c|c|c|c|c|c|c|c|c|c|}
\hline 11 & $\mathrm{~S}$ & $S$ & $S$ & $\mathrm{~S}$ & $\mathrm{~S}$ & $\mathrm{R}$ & $\mathrm{R}$ & $\mathrm{S}$ & $S$ & $22 \%$ \\
\hline 12 & $\mathrm{R}$ & S & $\mathrm{R}$ & I & $S$ & $\mathrm{~S}$ & $\mathrm{~S}$ & S & S & $22 \%$ \\
\hline 13 & $\mathrm{R}$ & S & $\mathrm{S}$ & $S$ & S & $S$ & S & S & S & $11 \%$ \\
\hline 14 & $\mathrm{R}$ & I & $\mathrm{R}$ & $\mathrm{S}$ & $S$ & $\mathrm{R}$ & $\mathrm{R}$ & $S$ & $S$ & $44 \%$ \\
\hline 15 & $\mathrm{R}$ & $S$ & I & $\mathrm{R}$ & $S$ & $\mathrm{~S}$ & $\mathrm{~S}$ & $S$ & $S$ & $22 \%$ \\
\hline 16 & $\mathrm{~S}$ & $S$ & $S$ & $\mathrm{~S}$ & $S$ & $\mathrm{R}$ & $\mathrm{S}$ & S & $S$ & $11 \%$ \\
\hline 17 & $\mathrm{R}$ & S & $\mathrm{R}$ & $\mathrm{S}$ & S & $\mathrm{S}$ & $\mathrm{S}$ & S & $S$ & $22 \%$ \\
\hline 18 & $\mathrm{~S}$ & $S$ & $S$ & $\mathrm{R}$ & I & $\mathrm{R}$ & $S$ & $S$ & $S$ & $22 \%$ \\
\hline 19 & $\mathrm{~S}$ & $S$ & $S$ & $\mathrm{~S}$ & $S$ & $\mathrm{R}$ & $S$ & $S$ & $S$ & $11 \%$ \\
\hline 20 & $\mathrm{R}$ & S & I & S & S & $\mathrm{R}$ & S & S & S & $22 \%$ \\
\hline 21 & $\mathrm{~S}$ & $S$ & $S$ & $\mathrm{~S}$ & $S$ & $\mathrm{R}$ & $S$ & $S$ & $S$ & $11 \%$ \\
\hline 22 & $\mathrm{~S}$ & S & $\mathrm{S}$ & $\mathrm{S}$ & $S$ & $\mathrm{~S}$ & $\mathrm{~S}$ & $\mathrm{R}$ & I & $11 \%$ \\
\hline 23 & $S$ & $S$ & $S$ & $\mathrm{~S}$ & $S$ & $S$ & $\mathrm{~S}$ & $S$ & $S$ & $0 \%$ \\
\hline 24 & $\mathrm{R}$ & $S$ & $\mathrm{R}$ & $\mathrm{S}$ & $S$ & $\mathrm{~S}$ & $\mathrm{R}$ & $S$ & $\mathrm{R}$ & $44 \%$ \\
\hline 25 & $\mathrm{~S}$ & I & $\mathrm{R}$ & $\mathrm{S}$ & $S$ & $S$ & $S$ & $S$ & $S$ & $11 \%$ \\
\hline 26 & $\mathrm{~S}$ & $S$ & $S$ & $\mathrm{~S}$ & $S$ & $S$ & $S$ & $S$ & $S$ & $0 \%$ \\
\hline 27 & I & $S$ & $S$ & I & $S$ & $S$ & $S$ & $S$ & $S$ & $0 \%$ \\
\hline 28 & I & $\mathrm{R}$ & $\mathrm{R}$ & $\mathrm{S}$ & $S$ & $\mathrm{R}$ & $S$ & I & $S$ & $33 \%$ \\
\hline 29 & I & $S$ & $S$ & $\mathrm{~S}$ & $S$ & $S$ & $S$ & $S$ & $S$ & $0 \%$ \\
\hline 30 & I & $S$ & $\mathrm{~S}$ & $\mathrm{~S}$ & $S$ & $\mathrm{~S}$ & $S$ & $S$ & $S$ & $0 \%$ \\
\hline 31 & $\mathrm{~S}$ & $S$ & $S$ & $\mathrm{~S}$ & $S$ & $S$ & $\mathrm{~S}$ & S & $S$ & $0 \%$ \\
\hline 32 & $\mathrm{~S}$ & S & $S$ & $\mathrm{~S}$ & $S$ & $\mathrm{~S}$ & $\mathrm{~S}$ & $S$ & S & $0 \%$ \\
\hline 33 & $\mathrm{~S}$ & $S$ & $S$ & $\mathrm{~S}$ & $S$ & $S$ & $S$ & $S$ & $S$ & $0 \%$ \\
\hline 34 & $\mathrm{~S}$ & $S$ & $S$ & $\mathrm{~S}$ & $S$ & $S$ & $S$ & $S$ & $S$ & $0 \%$ \\
\hline 35 & $\mathrm{R}$ & $S$ & $S$ & $\mathrm{~S}$ & $S$ & $\mathrm{~S}$ & $S$ & $S$ & $S$ & $11 \%$ \\
\hline 36 & $\mathrm{R}$ & I & $S$ & $\mathrm{R}$ & $S$ & $\mathrm{R}$ & $\mathrm{R}$ & $\mathrm{R}$ & $S$ & $56 \%$ \\
\hline 37 & $\mathrm{R}$ & $S$ & $\mathrm{R}$ & $\mathrm{S}$ & $S$ & $\mathrm{~S}$ & $S$ & $S$ & $S$ & $22 \%$ \\
\hline 38 & I & $S$ & $\mathrm{~S}$ & $\mathrm{~S}$ & $\mathrm{~S}$ & $\mathrm{~S}$ & I & $S$ & $S$ & $0 \%$ \\
\hline 39 & $\mathrm{R}$ & $S$ & $\mathrm{~S}$ & $\mathrm{~S}$ & $S$ & $\mathrm{R}$ & $\mathrm{R}$ & S & $S$ & $33 \%$ \\
\hline 40 & $\mathrm{R}$ & $S$ & $\mathrm{R}$ & $\mathrm{R}$ & $S$ & $S$ & $\mathrm{~S}$ & $S$ & $S$ & $33 \%$ \\
\hline 41 & $\mathrm{~S}$ & $S$ & $S$ & $\mathrm{~S}$ & $S$ & $\mathrm{R}$ & $\mathrm{R}$ & $S$ & $\mathrm{~S}$ & $22 \%$ \\
\hline 42 & $\mathrm{R}$ & $S$ & $\mathrm{R}$ & $\mathrm{R}$ & $\mathrm{R}$ & $\mathrm{R}$ & $S$ & $S$ & $\mathrm{~S}$ & $56 \%$ \\
\hline 43 & $\mathrm{~S}$ & $S$ & $\mathrm{~S}$ & $\mathrm{~S}$ & $S$ & $\mathrm{R}$ & $\mathrm{S}$ & $S$ & $S$ & $11 \%$ \\
\hline 44 & $\mathrm{R}$ & $S$ & $\mathrm{~S}$ & $S$ & $S$ & $\mathrm{R}$ & $S$ & $S$ & $S$ & $22 \%$ \\
\hline 45 & $\mathrm{R}$ & $S$ & $\mathrm{R}$ & $\mathrm{S}$ & $\mathrm{R}$ & $S$ & $\mathrm{R}$ & $\mathrm{R}$ & $S$ & $56 \%$ \\
\hline 46 & $\mathrm{R}$ & $\mathrm{S}$ & $\mathrm{S}$ & $\mathrm{S}$ & $\mathrm{S}$ & $\mathrm{S}$ & $\mathrm{S}$ & $\mathrm{S}$ & $\mathrm{S}$ & $11 \%$ \\
\hline Resistance & $46 \%$ & $11 \%$ & $35 \%$ & $15 \%$ & $0.07 \%$ & $35 \%$ & $17 \%$ & $0.09 \%$ & $0.02 \%$ & \\
\hline
\end{tabular}

AX; Amoxicillin, CTX; Cefotaxime, FOX; Cefoxitin, TOB; Tobramycin, CN; Gentamicin, TE; Tetracyclines, C;

Chloramphenicol, CIP; Ciprofloxacin, OFX; Ofloxacin, R; Resistant, S; Sensitive, I; Intermediate. 
Bacterial identification was carried out by MALDI-TOF mass spectrometry as follows; five isolates of $P$. aeruginosa, three isolates of Pr. mirabilis, in addition to a single isolate of $\mathrm{Kl}$. pneumoniae, Alc. faecalis, Ent. faecalis and B. cereus. Udden et al. [38] found that $P$. aeruginosa and Proteus sp. were the most prevalent bacterial isolates in patients ear discharge with OM infections. Alcaligenes faecalis (Alc. faecalis) is an opportunistic pathogen found in the human microbiome of the gastrointestinal tract. It is an uncommon cause of disease, especially OM. Udden et al. [38] isolated 19 Alc. faecalis strains from OM patients, and Filipe et al. (2017) [49] isolated fluoroquinolone-resistant Alc. faecalis from chronic suppurative OM. Both studies indicated that most Alc. faecalis isolates were from immunocompromised patients. On the other hand, the analysis of fungal isolates pattern, illustrated a high susceptibility to NYS (90.6\%). Only 3 isolates were resistant namely, $A$. niger, $A$. flavus and $P$. chrysogenum. Many researches and case reports for OM declared the susceptibility of fungal isolates to NYS, Chen et al. 2021 [50], who reported $73 \%$ of total cure rate when NYS used to treat OM. The same author [50] declared that the Aspergillus sp. was the leading causative fungal isolates $82.9 \%$ among 567 ear discharge swabs collected from patients diagnosed as otomycosis admitted to Department of Otolaryngology, Tongji Hospital, Tongji Medical Center, Wuhan, China. Overall, the identified MDR bacterial and resistant fungal strains in the present study are in accordance with other previous studies in Egypt and Africa [3,36,38,48,51]. These MDR strains are environmental organisms that are transmitted through water and soil [6] and opportunistic pathogens found in the human microbiome as Alc. faecalis [49], highlighted the importance of personal hygiene and the risk of immunocompromised patients to OM.

The increase in microbial resistance has become a major problem in the field of medicine and therapies[52]. Therefore, search for another effective therapeutic option is urgent. According to the European Pharmacopeia, the auricular solutions should be sterile and free of microbial load, antimicrobial preservatives [45]. Furthermore, natural organosulfur compounds within garlic are fundamental for providing innovative sources of novel antimicrobials against resistant pathogens[11,17]. For the above reasons, the current study was directed to evaluate the in vitro antibacterial and antifungal potentials of IAGE compared with AGE against the MDR isolates (12 bacterial and 3 fungal isolates) recovered from $\mathrm{OM}$ infections. This is in addition to evaluating in vitro enhancement of CIP, TOB and NYS inhibition activities by IAGE against the same strains. Firstly, prepared AGE was exposed to low doses of gamma irradiation( $0.25,0.5,0.75,1,2$, and $3 \mathrm{kGy}$ ). These doses were chosen in accounts for their global commonly use in natural products, herbs and spices irradiation especially for those containing organosulfur compounds [25]. Previous researches demonstrated that the $\gamma$-irradiation at dose of $10 \mathrm{kGy}$ (toxicologically and nutritionally confirmed maximum safe dose) or less, can eliminate the microbial load from herbs and spices without causing any changes in their chemical structure $[23,25,53]$. However, it is well-known that the organosulfur compounds as allicin are tightly related to the antimicrobial potency of garlic [54-56] and these compounds are sensitive to $\gamma$-irradiation, then, the usage of low doses are preferable to maintain their antimicrobial potency and preserve the golden advantage of $\gamma$-irradiation as a superior technique used to prolong AGE shelf life, storage period, and preservation $[55,56]$.

In the present study, non-significant differences in the direct inhibition potency between IAGE and AGE against the tested MDR strains were recorded. Figure (2) illustrates the fluctuation in the inhibition potency of IAGE on the growth inhibition of the tested MDR bacterial pathogens. In addition, no detectable change in inhibition potencies between IAGE and AGE could be found due to the direct effect of $\gamma$-radiation on water content of AGE not on its constituents. Garlic extract normally composes of $65 \% \mathrm{H}_{2} \mathrm{O}$ [8], in addition to sterile distilled water used to prepare the aqueous garlic extract. Gamma irradiation hydrolyzes water molecules $\left(\mathrm{H}_{2} \mathrm{O}\right)$ with releasing free radicals $\left(\mathrm{OH}^{-}, \mathrm{H}^{-}\right)$, electrons $\mathrm{e}_{\mathrm{aq}}{ }^{-}$, and molecular products $\left(\mathrm{H}_{2}, \mathrm{H}_{2} \mathrm{O}_{2}, \mathrm{H}_{3} \mathrm{O}^{+}\right)[34,57]$ as in equation (1):

$$
\mathrm{H}^{2} \mathrm{O} \underset{\gamma-\text { irradiation }}{\longrightarrow} \mathrm{OH}^{\cdot}+H^{\cdot}+e^{-}+H^{2} \mathrm{O}^{2}+\mathrm{H}^{2}+\mathrm{H}_{3} \mathrm{O}^{+} .
$$

It is known that these free radicals cause a decrease in the environmental $\mathrm{pH}$, which influences the bacterial growth. The presence of fluctuation in inhibition potencies within the same strains at the same dose of radiation in the present study could be due to indirect effect of $\gamma$-irradiation on the tested pathogens. This is because in-vivo physical orientation of free radicals or the environment not being conducive to the propagation of a free radical reaction [58]. 


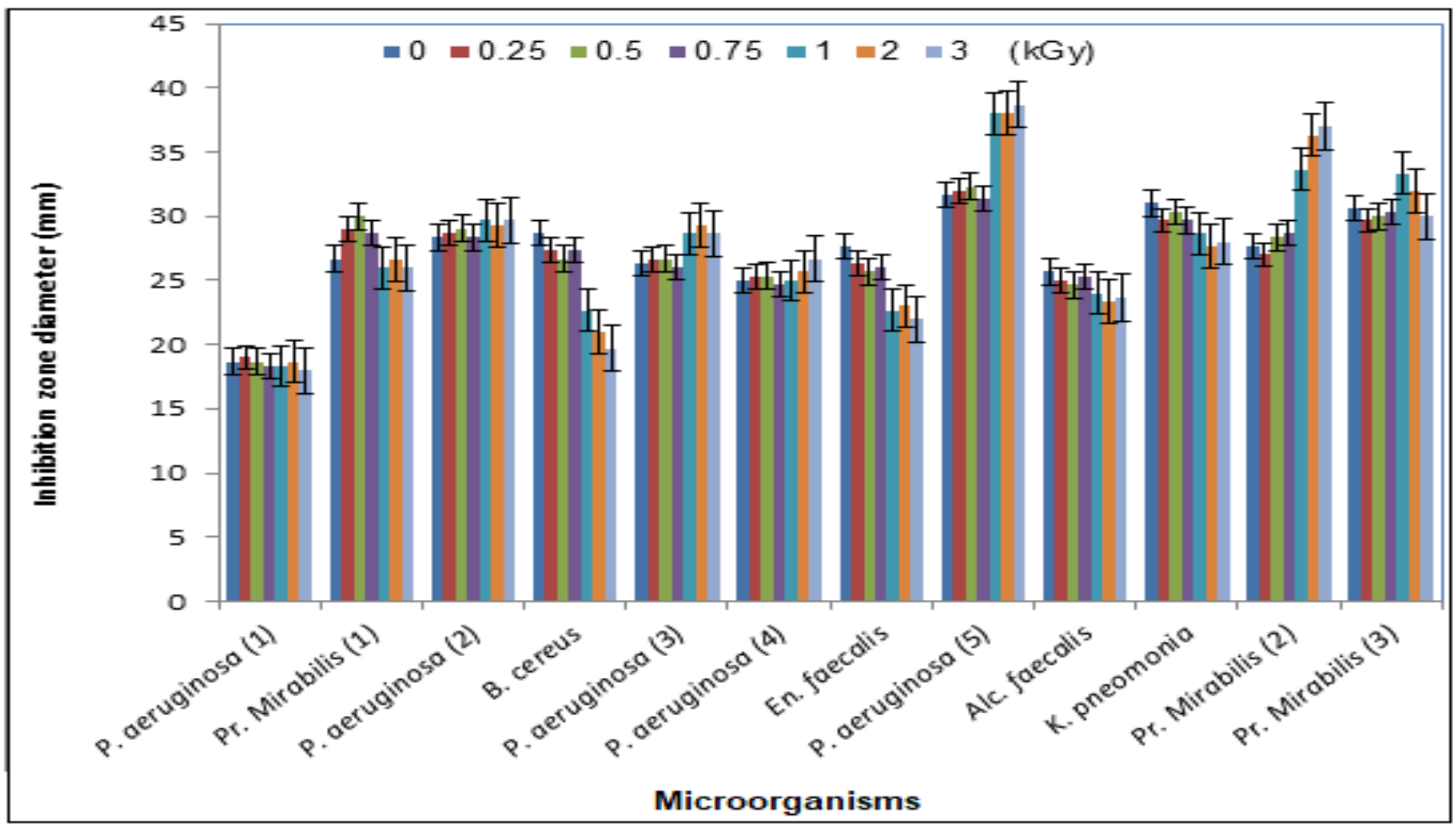

Fig. (2): Antibacterial activity of irradiated (0.25, 0.5, 0.75, 1, 2 and $3 \mathrm{kGy}$ ) aqueous garlic extract IAGE and control (0 kGy; AGE) against tested MDR bacterial strains isolated from OM infections. Error bars refer to standard deviation

The IZD of IAGE exposed to $0.25,0.5,0.75,1,2$ and $3 \mathrm{kGy}$ against the tested MDR bacterial strains isolated from $\mathrm{OM}$, were reported as $6 / 12(50 \%), 8 / 12(66.7 \%)$, $4 / 12$ (33.3\%), 6/12 (50\%), 8/12 (66.7\%), and 5/12 $(41.7 \%)$, respectively, higher than IZD of un-IAGE in each strain separately. Both IAGE (0.5 and $2 \mathrm{kGy})$ showed the highest inhibition potency $66.7 \%$ on the tested MDR pathogens. However, $0.5 \mathrm{kGy}$ was selected for further investigation (as a lower dose and had less distinctive smell than $2 \mathrm{kGy}$ ). This may suggest changing in one or more of the garlic sulfur containing compounds as; diallyl disulfide (which is defined as the main flavor component in garlic), alliin, allicin, thiosulfinates, amino acids sulfur containing compounds and others at a dose of $2 \mathrm{kGy}$. It is known that the volatile components of garlic are rich with sulfur compounds. This result had been recorded also by other researchers [59], who elucidated by thin layer chromatography and NMR spectroscopy assays, absence of changes in diallyl disulfide and other sulfur containing compounds structure or quantity at $0.05-0.5 \mathrm{kGy}$. While, $\gamma$-irradiation doses of 1-3 kGy increased the same tested compounds in garlic. This could explain the less smell occurrence at doses of $0.5 \mathrm{kGy}$ than $2 \mathrm{kGy}$ in the present study. Furthermore, 0.5 IAGE was chosen because the dose of $0.5 \mathrm{kGy}$ is more safe, and can decrease/inactivate the AGE food borne pathogens or spoilages microorganisms and microbial load without causing modifications in AGE constituents' structure, as reported before by many authors [56,59]. Moreover, this dose is below $1 \mathrm{kGy}$, which recorded before by [25] as causing an increase in the temperature of herb products by $0.36^{\circ} \mathrm{C}$.

In the current study, IAGE inhibited all MDR bacterial strains at concentrations up to $31.25 \mathrm{mg} / \mathrm{mL}$. IAGE activity was in a concentration dependent manner, but not strain dependent manner (Table 3A). These observations are in accordance with another study [60], which indicated a broad spectrum activity of IAGE against Gram-positive and Gram-negative bacteria. The variation in the size of the inhibition zones among the tested MDR strains could be attributed to the lipid content of the bacterial membranes which facilitates the passage of allicin and other bioactive garlic constituents to permeate bacterial membrane [19]. Li et al. [61] reported that the combination of AGE and some antibiotics could improve the antibiotic sensitivity of some pathogens. All tested MDR bacterial strains showed statistically significant differences $(P<0.001)$ in their IZD when CIP was combined with IAGE as compared to the same concentration of CIP alone (as shown in Table 3A), which indicated a synergistic effect, 
confirmed by statistical analysis. The IZD around the tested strains were increased by $5-13 \mathrm{~mm}$ after combination. For TOB, combination with IAGE showed a statistically significant difference of $P<0.05$ and $P<$ 0.001 in six strains each compared with TOB alone (Table 3A). This was observed as an increase in IZD by 2-8 mm. Cai et al. [62] found that when allicin was combined with cefazolin, oxacillin, or cefoperazone, it stimulated the activities of these $\beta$-lactam antibiotics in a synergistic fashion against $P$. aeruginosa, Staphylococcus aureus, and S. epidermidis. Li et al. [61] reported that the combination of CTX, levofloxacin, ceftriaxone, cefazolin, or ampicillin with fresh garlic extract could produce larger inhibition zones against $P$. aeruginosa as compared with the antibiotics used alone. $\mathrm{Jia}$ and $\mathrm{Wu}$ [52] showed that the antibacterial activity against Shigella sp. Was increased after the combined use of antibiotics with allicin extracted from AGE. Cai et al. [62] suggested that the potential for the clinical use of combinations of antimicrobials and garlic extract was huge since it might render some untreatable resistant infections as treatable at currently recommended dosages that are often marginally effective against resistant species when used alone.

Table (3A): Minimum inhibitory concentration (MIC) and related inhibition zone diameter (IZD) of irradiated aqueous garlic extract IAGE, ciprofloxacin and tobramycin alone and IZD after the combination of the same MIC's against the tested MDR bacterial strains

\begin{tabular}{|c|c|c|c|c|c|}
\hline Treatment & $\begin{array}{c}\text { IAGE } \\
\text { MIC }(\mathrm{mg} / \mathrm{ml}) / \\
\mathrm{IZD}(\mathrm{mm})\end{array}$ & $\begin{array}{c}\text { CIP } \\
\text { MIC }(\mathrm{mg} / \mathrm{ml}) / \\
\operatorname{IZD}(\mathrm{mm})\end{array}$ & $\begin{array}{c}\text { TOB } \\
\text { MIC }(\mathrm{mg} / \mathrm{ml}) / \\
\mathrm{IZD}(\mathrm{mm})\end{array}$ & $\begin{array}{l}\text { IAGE+CIP } \\
\text { IZD (mm) }\end{array}$ & $\begin{array}{c}\text { IAGE+TOB } \\
\text { IZD }(\mathrm{mm})\end{array}$ \\
\hline P. aeruginosa (1) & $\begin{array}{c}125 / \\
17.33 \pm 1.53\end{array}$ & $\begin{array}{c}0.02 / \\
26.00 \pm 1.73 \mathrm{a}\end{array}$ & $\begin{array}{c}0.046 / \\
22.67 \pm 1.53 \mathrm{a}\end{array}$ & $\begin{array}{c}32.67 \pm 1.15 \\
* * a b\end{array}$ & $\begin{array}{c}25.67 \pm 0.58 \\
* a b\end{array}$ \\
\hline Pr. Mirabilis (1) & $\begin{array}{c}62.5 / \\
17.67 \pm 1.53\end{array}$ & $\begin{array}{c}0.02 / \\
25.33 \pm 1.53 \mathrm{a}\end{array}$ & $\begin{array}{c}0.09 / \\
19.33 \pm 0.58\end{array}$ & $\begin{array}{c}31.00 \pm 2.00 \\
* * \mathrm{ab}\end{array}$ & $\begin{array}{c}24.67 \pm 1.53 \\
* * a b\end{array}$ \\
\hline P. aeruginosa (2) & $\begin{array}{c}62.5 / \\
21.00 \pm 1.00\end{array}$ & $\begin{array}{c}0.02 / \\
24.67 \pm 0.58 \mathrm{a}\end{array}$ & $\begin{array}{c}0.09 / \\
19.67 \pm 1.53\end{array}$ & $\begin{array}{c}31.00 \pm 2.00 \\
* * \mathrm{ab}\end{array}$ & $26.67 \pm 1.15 * * a b$ \\
\hline B. cereus & $\begin{array}{c}62.5 / \\
18.67 \pm 1.53\end{array}$ & $\begin{array}{c}0.02 / \\
20.33 \pm 2.08 \mathrm{a}\end{array}$ & $\begin{array}{c}0.046 / \\
24.33 \pm 0.58 \mathrm{a}\end{array}$ & $\begin{array}{c}25.67 \pm 1.00 \\
* * \mathrm{ab}\end{array}$ & $\begin{array}{c}26.67 \pm 1.53 \\
* a b\end{array}$ \\
\hline P. aeruginosa (3) & $\begin{array}{c}31.25 / \\
19.33 \pm 1.53\end{array}$ & $\begin{array}{c}0.046 / \\
20.33 \pm 1.53\end{array}$ & $\begin{array}{c}0.09 / \\
22.33 \pm 1.53\end{array}$ & $\begin{array}{c}26.33 \pm 1.15 \\
* * \mathrm{a}\end{array}$ & $\begin{array}{c}27.00 \pm 1.73 \\
* a b\end{array}$ \\
\hline P. aeruginosa (4) & $\begin{array}{c}62.5 / \\
14.33 \pm 1.15\end{array}$ & $\begin{array}{c}0.02 / \\
19.0 \pm 2.08 \mathrm{a}\end{array}$ & $\begin{array}{c}0.046 / \\
21.33 \pm 1.53 \mathrm{a}\end{array}$ & $24.33 \pm 1.53 * *$ & $\begin{array}{c}26.67 \pm 1.53 \\
* * a b\end{array}$ \\
\hline Ent. faecalis & $\begin{array}{c}31.25 / \\
17.00 \pm 2.00\end{array}$ & $\begin{array}{c}0.02 / \\
20.67 \pm 1.53 \mathrm{a}\end{array}$ & $\begin{array}{c}0.09 / \\
20.67 \pm 1.15 \mathrm{a}\end{array}$ & $\begin{array}{c}25.67 \pm 1.53 \\
* * a b\end{array}$ & $\begin{array}{c}27.33 \pm 1.53 \\
* * a b\end{array}$ \\
\hline P. aeruginosa (5) & $\begin{array}{c}62.5 / \\
17.33 \pm 0.58\end{array}$ & $\begin{array}{c}0.75 / \\
17.33 \pm 1.15\end{array}$ & $\begin{array}{c}0.1875 / \\
18.33 \pm 1.15\end{array}$ & $\begin{array}{c}23.67 \pm 1.53 \\
* * a b\end{array}$ & $\begin{array}{c}25.33 \pm 1.53 \\
* * a b\end{array}$ \\
\hline Alc. faecalis & $\begin{array}{c}62.5 / \\
20.67 \pm 1.15\end{array}$ & $\begin{array}{c}0.02 / \\
24.00 \pm 1.73 \mathrm{a}\end{array}$ & $\begin{array}{c}0.046 / \\
18.67 \pm 1.15\end{array}$ & $\begin{array}{c}29.67 \pm 0.58 \\
* * \mathrm{ab}\end{array}$ & $\begin{array}{c}24.00 \pm 1.00 \\
*_{\mathrm{ab}}\end{array}$ \\
\hline Kl. pneumoniae & $\begin{array}{c}31.25 / \\
19.67 \pm 1.15\end{array}$ & $\begin{array}{c}0.02 / \\
20.67 \pm 2.08 \mathrm{a}\end{array}$ & $\begin{array}{c}0.09 / \\
15.67 \pm 0.58 \mathrm{a}\end{array}$ & $\begin{array}{c}31.67 \pm 1.53 \\
* * a b\end{array}$ & $\begin{array}{c}23.67 \pm 1.15 \\
* b\end{array}$ \\
\hline Pr. Mirabilis (2) & $\begin{array}{c}62.5 / \\
19.67 \pm 1.53\end{array}$ & $\begin{array}{c}0.02 / \\
18.67 \pm 1.53\end{array}$ & $\begin{array}{c}0.046 / \\
22.33 \pm 1.15\end{array}$ & $\begin{array}{c}23.67 \pm 1.15 \\
* * a b\end{array}$ & $\begin{array}{c}28.33 \pm 1.53 \\
* * a b\end{array}$ \\
\hline Pr. Mirabilis (3) & $\begin{array}{c}31.25 / \\
14.67 \pm 1.53\end{array}$ & $\begin{array}{c}0.02 / \\
19.67 \pm 1.53 \mathrm{a}\end{array}$ & $\begin{array}{c}0.046 / \\
17.67 \pm 1.53\end{array}$ & $\begin{array}{c}32.33 \pm 1.53 \\
* * a b\end{array}$ & $\begin{array}{c}21.33 \pm 1.53 \\
* a b\end{array}$ \\
\hline
\end{tabular}

IAGE; Irradiated aqueous garlic extract at a dose of $0.5 \mathrm{kGy}$, CIP; Ciprofloxacine, TOB; Tobramycin, MIC; Minimum inhibitory concentration, IZD; Inhibition zone diameter. Values represent the mean \pm SD $(n=3)$. Data within the groups were analyzed using ANOVA followed by $\mathrm{a}-\mathrm{b}$ Duncan's multiple range test (DMRT). *; $\mathrm{P}<0.05$ significant; $* * ; P<0.001$ highlysignificant. 
On the other hand, fungal strains were inhibited by up to $50 \%$ concentration of IAGE, and the activity was increased in concentration dependent manner. These results are in agreement with a previous study [63]. While, the same fungal strains were inhibited by NYS at concentrations up to $12.5 \mathrm{mg} / \mathrm{m}$. The IZD around NYS with IAGE against $A$. niger, $A$. flavus, and $P$. chrysogenum were increased by $15,7.8$, and $16 \mathrm{~mm}$, respectively as compared to the same concentration of NYS alone, with a statistically significant difference $(P<0.001)$ as shown in Table (3B). Li et al. [61] found that fresh garlic extract showed a potent inhibitory effect against Candida albicans as compared with fluconazole and itraconazole, and the fungistatic activity of these antifungals was dramatically enhanced by the addition of fresh garlic extract.

Table (3 B): Minimum inhibitory concentration (MIC) with related inhibition zone diameter (IZD) of irradiated aqueous garlic extract IAGE and nystatin alone and IZD after combinations against MDR fungal strains

\begin{tabular}{l|c|c|c}
\hline Treatment & IAGE & NYST & IAGE+NYS \\
& $\begin{array}{c}\mathrm{MIC} \\
(\mathrm{mg} / \mathrm{ml}) / \\
\mathrm{IZD}(\mathrm{mm})\end{array}$ & $\begin{array}{c}\mathrm{MIC} \\
(\mathrm{mg} / \mathrm{ml}) /\end{array}$ & $\mathrm{IZD}(\mathrm{mm})$ \\
Fungal strain $(\mathrm{mm})$ \\
\hline Aspergillus niger & $125 /$ & $25 /$ & $34.67 \pm 1.53$ \\
& $27.67 \pm 0.58$ & $19.67 \pm 1.53 \mathrm{a}$ & $* * \mathrm{ab}$ \\
Aspergillus flavus & $21.67 \pm 1.53$ & $19.67 \pm 1.53$ & $\begin{array}{c}27.47 \pm 0.58 \\
* * \mathrm{~b}\end{array}$ \\
$\begin{array}{l}\text { Penicillium } \\
\text { chrysogenum }\end{array}$ & $21.67 \pm 1.53$ & $23.33 \pm 1.53 \mathrm{a}$ & $* * \mathrm{ab}$ \\
\hline
\end{tabular}

IAGE; Irradiated aqueous garlic extract at a dose of $0.5 \mathrm{kGy}$ NYS; Nystatin, MIC: Minimum inhibitory concentration, IZD; Inhibition zone diameter. Values represent the mean \pm SD ( $n=$ 3). Data within the groups were analyzed using ANOVA followed by a\&b Duncan's multiple range test (DMRT). *; $P<0.05$ significant; **; $P<0.001$ highly significant.

TEM images were used to study the ultrastructure of $P$. aeruginosa (2) before and after treatment with CIP alone and in combination with IAGE. TEM images of untreated $P$. aeruginosa (2) cells showed the protoplast as differentiated into a cytoplasmic region, and cell wall. The cell wall appeared rigid and intact, retaining its structural integrity (Fig. 3A). In contrast, the ultrathin sections of $P$. aeruginosa (2) treated with $0.02 \mathrm{mg} / \mathrm{mL}$ of
CIP showed cytoplasmic shrinkage, and only some bacterial cells were able to maintain their typical pattern, as shown in Fig. (3B). When P. aeruginosa was treated with the combination of $62.5 \mathrm{mg} / \mathrm{mL}$ of IAGE and $0.02 \mathrm{mg} / \mathrm{mL}$ of CIP, the bacterial cells showed extensive cytoplasmic shrinkage and severe vacuolation of the cellular material, with some cells showing complete loss of nuclear and cytoplasmic material and rupture of the cell membrane (Fig. 3C). These findings were consistent with those of other authors [31], who found that exposure to organosulfur compounds extracted from garlic resulted in morphological damage, such as loss of the structural integrity of the cell wall, cell membrane, and intracellular matrix. Cell deformation, the breakage of cell walls and membranes, condensation of cellular material, and the presence of significant amounts of cytoplasmic material and membrane fragments were also observed in the damaged bacterial cells. On the other hand, the ultrastructure study of the cells of untreated $A$. flavus showed normal hyphae with typical cell wells, membranes, and organelles (Fig. 4A). After treatment with $12.5 \mathrm{mg} / \mathrm{mL}$ of NYS, the ultrastructure of the cell wall and cell membrane became degraded (Fig. 4B), and the hyphae started to break. Furthermore, a severe damage and disappearance of the cell wall and membrane were observed, with empty spaces observed inside the cells due to the degradation of the organelles. Fig. (4C) also shows mitochondrial fragmentation and shrinkage of the cell membrane, with separation of the fungal cells. Generally, TEM studies of A. flavus treated with IAGE proved its ability to act on the cell wall, cell membrane, and cytoplasmic components, causing dissolution and increased vacuolization. This was also observed by other investigators [64], who proved that allicin and AGE damaged, disorganized, and caused the dissolution of cytoplasmic contents as well as the detachment of the cell membrane from the cell wall. Gupta and Porter [65] found that garlic extract contains allylamines, a class of antifungal compounds containing a chemical group naturally found in garlic. This compound causes the accumulation of squalene monooxygenase, an important enzyme involved in the formation of the walls of fungal cells. This blocks the formation of ergosterol, which is essential for the synthesis of fungal cell walls. 

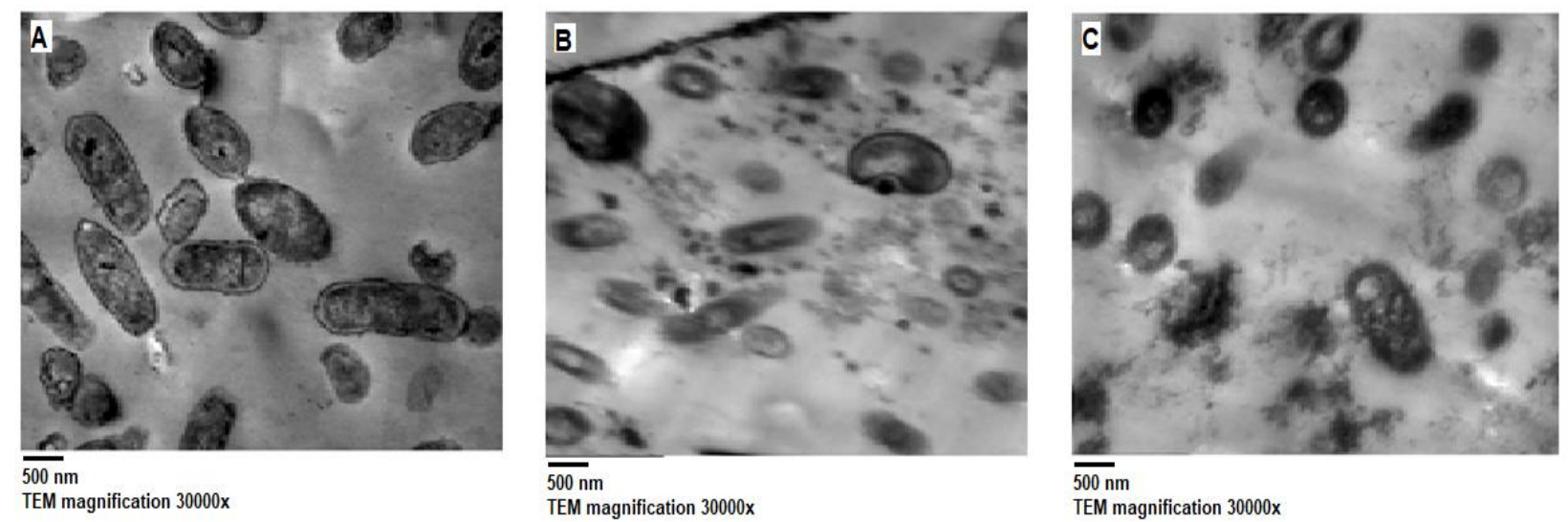

Fig. (3): TEM images of Pseudomonas aeruginosa no.2, (A) untreated, (B) treated with $0.02 \mathrm{mg} / \mathrm{mL}$ of CIP and $(C)$ treated with combination of $62.5 \mathrm{mg} / \mathrm{mL}$ of IAGE and $0.02 \mathrm{mg} / \mathrm{mL}$ of CIP

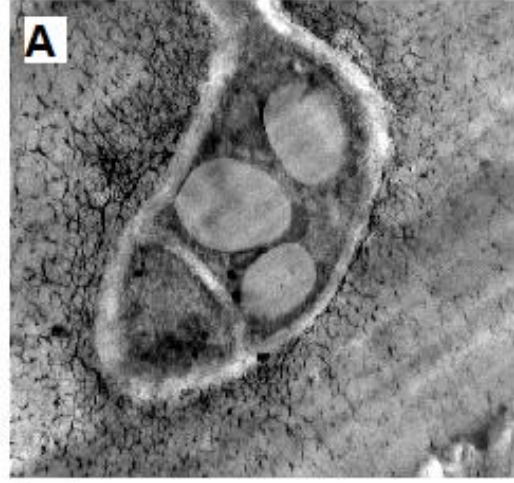

$500 \mathrm{~nm}$

TEM magnification $15000 x$

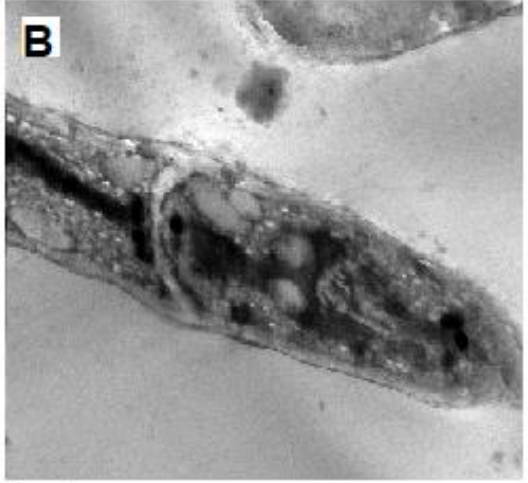

$\overline{500 \mathrm{~nm}}$

TEM magnification $15000 x$

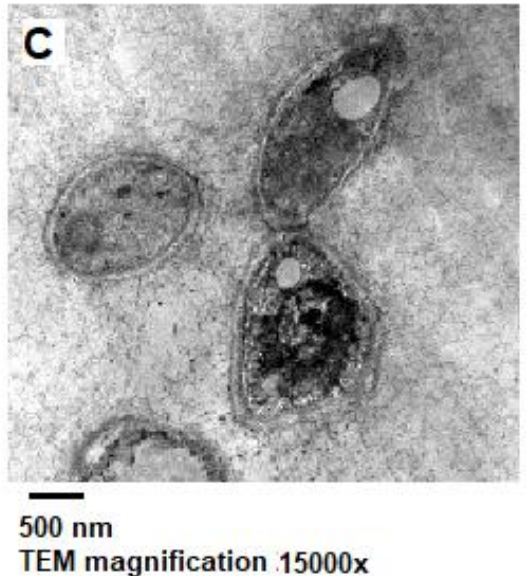

TEM magnification $15000 \mathrm{x}$

Fig. (4): TEM images of Aspergillus flavus, (A) a typical untreated hypha with normal cell wall, cell membrane and organelles, (B) after being treated with $12.5 \mathrm{mg} / \mathrm{mL}$ of NYS and (C) after being treated with combination of $250 \mathrm{mg} / \mathrm{mL}$ of IAGE and $12.5 \mathrm{mg} / \mathrm{mL}$ of NYS

\section{CONCLUSION}

The present study highlights the fact that OM occurs not only in children, but also in adults with a higher percentage, representing a broad community and health problem. High prevalence of bacterial than fungal isolates with the absence of yeasts was observed. P. aeruginosa and Aspergillus spp. are the most common bacterial and fungal isolates, respectively, that exhibited a high level of resistance to commonly used drugs for OM treatment. Therefore, culture and susceptibility tests are of a paramount importance to better manage $\mathrm{OM}$ and drug-resistant infections. Irradiated fresh aqueous garlic extract may be used to aid the treatment of infections caused by MDR microbial pathogens alone as a natural, safe, cheap, available and sterile auricular solution better than the commonly used antibiotics. In the current study, the combination of IAGE with CIP or NYS demonstrates a significant inhibition for bacterial and fungal growth as compared with each of them alone. This could help to recover the potency of some older and cheaper antibiotics with low activity. Furthermore, it can be used to reduce the required therapeutic dosage, leading to a substantial effect in medical, community, and commercial sittings. The present study suggests the use of AGE alone and in combination with other antibiotics or antifungals to treat MDR bacterial and fungal isolates that cause OM in vitro. However, it is difficult to predict the in vivo synergistic effects. Thus, detailed in vivo pharmacokinetic studies of garlic alone and in combination with antimicrobials are necessary. 


\section{ABBREVIATIONS}

AGE: aqueous garlic extract; AX: amoxicillin; C: chloramphenicol; CIP: ciprofloxacin ; CN: gentamicin; CTX: cefotaxime; FOX: cefoxitin; IAGE: irradiated AGE; IZD: inhibition zone diameter; MDR: multidrugresistant; MICs: minimum inhibitory concentrations; NYS: nystatin; OM: otitis media; OFX: ofloxacin; SDA: sabouraud dextrose agar; TE: tetracycline; TEM: Transmission electron microscopy; TOB: tobramycin.

\section{ACKNOWLEDGEMENTS}

The authors would like to sincerely thank Prof. Dr. Mervat Elanany, leader manager for Microbiology laboratory at Children's Cancer Hospital 57357, Giza, Egypt, for her assistance in identification of MDR bacterial isolates.

\section{CONFLICT OF INTERESTS}

All authors declared that they have no conflict of interests

\section{AUTHORS' CONTRIBUTIONS}

HNE and AGH conceived of the study, participated in its design and coordination, also made the definitions of intellectual content and supervised the whole research. EAM, HGN and HNE made literature research. EAM collected the samples and identified the isolates, also performed the experimental studies, data acquisition, data analysis and statistical analysis. HGN participated in isolates identification and assisted in the whole steps of research work. HGN, HNE and RAK organized and analyzed the final data. HGN wrote the original draft and the final manuscript. HNE revised the final manuscript. All authors read and approved the final manuscript.

\section{FUNDING}

This research did not receive any specific fund from funding agencies in the public, commercial, or non-profit sectors.

\section{AVAILABILITY OF DATA AND MATERIALS}

Author on request

\section{ETHICS APPROVAL}

Not applicable.

\section{CONSENT FOR PUBLICATION}

Not applicable.

\section{REFERENCES}

[1] Onali, M.A., Bareeqa, S.B., Zia, S., Ahmed, S.I., Owais, A., and Ahmad, A.N. (2018). Efficacy of Empirical Therapy With Combined Ciprofloxacin Versus Topical Drops Alone in Patients With Tubotympanic Chronic Suppurative Otitis Media: A Randomized Double-Blind Controlled Trial. Clinical medicine insights. Ear, Nose and Throat 11,1-6.

[2] Sarrell, E.M., Mandelberg, A., and Cohen, H.A. (2001). Efficacy of naturopathic extracts in the management of ear pain associated with acute otitis media. Archives of Pediatrics and Adolescent Medicine 155, 796-799.

[3] Ghaly, M.F., Shaheen, A.A., Bouhy, A.M., and Bendary, M.M. (2020). Alternative therapy to manage otitis media caused by multidrug-resistant fungi. Archives of Microbiology 202, 1231-1240.

[4] Patel, K.N., Shrimali, G.P., and Thakor, N. (2016). A study of fungi isolated from cases of otitis media diagnosed at tertiary care hospital of Gujarat, India. International Journal of Advances in Medicine 3, 832-834.

[5] Silva, M.D., and Sillankorva, S. (2019). Otitis media pathogens - A life entrapped in biofilm communities. Critical Reviews in Microbiology 45, 595-612.

[6] Hailegiyorgis, T.T., Sarhie, W.D., and Workie, H.M. (2018). Isolation and antimicrobial drug susceptibility pattern of bacterial pathogens from pediatric patients with otitis media in selected health institutions, Addis Ababa, Ethiopia: A prospective cross-sectional study. BMC Ear, Nose and Throat Disorders 18, 1-7.

[7] Marchese, A., Barbieri, R., Sanches-Silva, A., Daglia, M., Nabavi, S.F., Jafari, N.J., Izadi, M., Ajami, M., and Nabavi, S.M. (2016). Antifungal and antibacterial activities of allicin: A review. Trends in Food Science and Technology 52, 49-56.

[8] Mohamed Ismail, R., Hamoud Ahmed Saleh, A., Saeed Ali, K., and Author, C. (2020). GC-MS analysis and antibacterial activity of garlic extract with antibiotic. Journal of Medicinal Plants Studies 8, 26-30.

[9] Farrag, H.A., Hosny, A.E.D.M.S., Hawas, A.M., Hagras, S.A.A., and Helmy, O.M. (2019). Potential efficacy of garlic lock therapy in combating biofilm and catheter-associated infections; experimental 
studies on an animal model with focus on toxicological aspects. Saudi Pharmaceutical Journal $27,830-840$.

[10] Deresse, D. (2010). Antibacterial Effect of Garlic (Allium sativum) on Staphylococcu aureus: An in vitro Study. Asian Journal of Medical Sciences 2, $62-65$.

[11] Hrbek, V., Rektorisova, M., Chmelarova, H., Ovesna, J., and Hajslova, J. (2018). Authenticity assessment of garlic using a metabolomic approach based on high resolution mass spectrometry. Journal of Food Composition and Analysis 67, 1928.

[12] Kyung, K.H., Kim, M.H., Park, M.S., and Kim, Y.S. (2002). Alliinase-independent inhibition of Staphylococcus aureus B33 by heated garlic. Journal of Food Science 67, 780-785.

[13] Block, E., Bechand, B., Gundala, S., Vattekkatte, A., Wang, K., Mousa, S., Godugu, K., Yalcin, M., and Mousa, S. (2017). Fluorinated analogs of organosulfur compounds from garlic (Allium sativum): Synthesis, chemistry and antiangiogenesis and antithrombotic studies. Molecules 22, 2081.

[14] Kim, W.T., Seo, S.P., Byun, Y.J., Kang, H.W., Kim, Y.J., Lee, S.C., Jeong, P., Song, H.J., Choe, S.Y., Kim, D.J., et al. (2018). The anticancer effects of garlic extracts on bladder cancer compared to cisplatin: A common mechanism of action via centromere protein M. American Journal of Chinese Medicine 46, 689-705.

[15] Petropoulos, S., Fernandes, Â., Barros, L., Ciric, A., Sokovic, M., and Ferreira, I.C.F.R. (2018). Antimicrobial and antioxidant properties of various Greek garlic genotypes. Food Chemistry 245, 7-12.

[16] Shang, A., Cao, S.-Y., Xu, X.-Y., Gan, R.-Y., Tang, G.-Y., Corke, H., Mavumengwana, V., and Li, H.B. (2019). Bioactive compounds and biological functions of garlic (Allium sativum L.). Foods 8 , 246.

[17] Leontiev, R., Hohaus, N., Jacob, C., Gruhlke, M.C.H., and Slusarenko, A.J. (2018). A comparison of the antibacterial and antifungal activities of thiosulfinate analogues of allicin. Scientific Reports 8,6763 .

[18] Sivam, G.P. (2001). Protection against Helicobacter pylori and other bacterial infections by garlic. In
Journal of Nutrition (American Institute of Nutrition), pp. 1106-1108.

[19] Miron, T., Rabinkov, A., Mirelman, D., Wilchek, M., and Weiner, L. (2000). The mode of action of allicin: Its ready permeability through phospholipid membranes may contribute to its biological activity. Biochimica et Biophysica Acta - Biomembranes 1463, 20-30.

[20] Gruhlke, M.C.H., Portz, D., Stitz, M., Anwar, A., Schneider, T., Jacob, C., Schlaich, N.L., and Slusarenko, A.J. (2010). Allicin disrupts the cell's electrochemical potential and induces apoptosis in yeast. Free Radical Biology and Medicine 49, 1916-1924.

[21] Kebeish, R., Deef, E., and El-Bialy, N. (2015). Effect of gamma radiation on growth, oxidative stress, antioxidant system, and alliin producing gene transcripts in Allium sativum. International Journal of Research Studies in Biosciences (IJRSB) $3,161-174$.

[22] Codex Alimentarius Commission (2003). General Standard for Irradiated Foods, CODEX STAN. General Standard for Irradiated Foods (CODEX STAN 106-1983, Rev.1-2003), FAO/WHO, Rome.

[23] Farkas, J. (2006). Irradiation for better foods. Trends in Food Science and Technology 17, 148152.

[24] Ahn, J.J., Kim, G.R., Akram, K., Kim, K.S., and Kwon, J.H. (2012). Effect of storage conditions on photostimulated luminescence of irradiated garlic and potatoes. Food Research International 47, 315320.

[25] Sádecká, J. (2017). Irradiation of spices-A review. Czech Journal of Food Sciences 25, 231-242.

[26] Saif, F.A., Yaseen, S.A., Alameen, A.S., Mane, S.B., and Undre, P.B. (2021). Identification and characterization of Aspergillus species of fruit rot fungi using microscopy, FT-IR, Raman and UVVis spectroscopy. Spectrochimica Acta - Part A: Molecular and Biomolecular Spectroscopy 246, 119010.

[27] Bauer, and AW (1966). Antibiotic susceptibility testing by a standardized single disc method. American Journal of Clinical Pathology 45, 149158.

[28] WAYNE, and PA (2010). Clinical and Laboratory Standards Institute: Performance standards for 
antimicrobial susceptibility testing: 20th informational supplement. 27th ed.

[29] Iwalokun, B.A., Ogunledun, A., Ogbolu, D.O., Bamiro, S.B., and Jimi-Omojola, J. (2004). In vitro antimicrobial properties of aqueous garlic extract against multidrug-resistant bacteria and Candida species from Nigeria. Journal of Medicinal Food 7, 327-333.

[30] Andualem, B. (2013). Combined antibacterial activity of stingless bee (Apis mellipodae) honey and garlic (Allium sativum) extracts against standard and clinical pathogenic bacteria. Asian Pacific Journal of Tropical Biomedicine 3, 725731.

[31] Lu, X., Rasco, B.A., Jabal, J.M.F., Eric Aston, D., Lin, M., and Konkel, M.E. (2011). Investigating antibacterial effects of garlic (Allium sativum) concentrate and garlic-derived organosulfur compounds on Campylobacter jejuni by using fourier transform infrared spectroscopy, Raman spectroscopy, and electron microscopy. Applied and Environmental Microbiology 77, 5257-5269.

[32] Xin Hua Zhou, and Alain Li Wan Po (1991). Comparison of enzyme activities of tissues lining portals of absorption of drugs: Species differences. International Journal of Pharmaceutics 70, 271283.

[33] Harter, H.L. (1960). Critical Values for Duncan's New Multiple Range Test. Biometrics 16, 671.

[34] El-Batal, A.I., Nada, H.G., El-Behery, R.R., Gobara, M., and El-Sayyad, G.S. (2020). Nystatinmediated bismuth oxide nano-drug synthesis using gamma rays for increasing the antimicrobial and antibiofilm activities against some pathogenic bacteria and: Candida species. RSC Advances 10, 9274-9289.

[35] Al-Yas, M.C.. (2011). Evaluate the antibacterial effect of garlic (Allium sativum) and antimicrobial susceptibility on Pseudomonas aeruginosa isolated from otitis media. Al-Mustansiriyah Journal for Pharmaceutical Sciences 10, 94-104.

[36] AbAmeer Saleh Á, M., Abdul Amir Saleh Ȧ, I., Abdul Amir Saleh B, N., and M B Ȧ, M.S. (2014). Bacteria and Fungi associated with Acute Otitis Media. International Journal of Current Engineering and Technology 4, 316-318.

[37] Ganesh, V.B., and Subramaniam, T.P. (2015). Bacteriological and mycological profile of chronic suppurative otitis media in a tertiary teaching hospital, Trichy, Tamilnadu. International Journal of Pharmaceutical Science Invention ISSN 4, 1319.

[38] Uddén, F., Filipe, M., Reimer, A., Paul, M., Matuschek, E., Thegerström, J., Hammerschmidt, S., Pelkonen, T., and Riesbeck, K. (2018). Aerobic bacteria associated with chronic suppurative otitis media in Angola. Infectious Diseases of Poverty 7, $1-10$.

[39] Loy, A.H.C., Tan, A.L., Lu, K.S., and Loy, A. (2002). Microbiology of chronic suppurative otitis media in Singapore. Singapore Med J 43, 296-299.

[40] Block, S.L. (1997). Causative pathogens, antibiotic resistance and therapeutic considerations in acute otitis media. Pediatric Infectious Disease Journal $16,449-456$.

[41] Mustafa, E.A., Hashem, A.E.G., Elhifnawi, H.N., Nada, H.G., and Khattab, R.A. (2021). One-pot biosynthesis of silver nanoparticles with potential antimicrobial and antibiofilm efficiency against otitis media-causing pathogens. European Journal of Clinical Microbiology and Infectious Diseases $40,49-58$.

[42] Araby, E., Nada, H.G., Abou El-Nour, S.A., and Hammad, A. (2020). Detection of tetracycline and streptomycin in beef tissues using Charm II, isolation of relevant resistant bacteria and control their resistance by gamma radiation. BMC Microbiology 20, 186.

[43] Brennan-Jones, C.G., Head, K., Chong, L.Y., Burton, M.J., Schilder, A.G.M., and Bhutta, M.F. (2020). Topical antibiotics for chronic suppurative otitis media. Cochrane Database of Systematic Reviews 2020.

[44] Fradis, M., Brodsky, A., Ben-David, J., Srugo, I., Larboni, J., and Podoshin, L. (1997). Chronic otitis media treated topically with ciprofloxacin or tobramycin. Archives of Otolaryngology - Head and Neck Surgery 123, 1057-1060.

[45] Chappe, M., Vrignaud, S., de Gentile, L., Legrand, G., Lagarce, F., and Le Govic, Y. (2018). Successful treatment of a recurrent Aspergillus niger otomycosis with local application of voriconazole. Journal de Mycologie Medicale 28, 396-398.

[46] Pichichero, M.E. (2005). Preferred antibiotics for treatment of acute otitis media: Comparison of 
practicing pediatricians, general practitioners, and otolaryngologists. Clinical Pediatrics 44, 575-578.

[47] A Abdelshafy, I. (2015). Microbiology of chronic suppurative otitis media, study of the role of bacterial biofilm and fungal infection. Journal of Otolaryngology-ENT Research 3, 00051.

[48] Shamsuddeen, U., Usman, A.D., Bukar, A., and Safiya, I. (2010). Dacterial agents of otitis media and their sensitivity to some antibiotics in Aminu kano teaching hospital, Kano state. Bayero Journal of Pure and Applied Sciences 3, 191-194.

[49] Filipe, M., Reimer, Å., Matuschek, E., Paul, M., Pelkonen, T., and Riesbeck, K. (2017). Fluoroquinolone-resistant Alcaligenes faecalis related to chronic suppurative otitis media, Angola. Emerging Infectious Diseases 23, 1740-1742.

[50] Chen, Q., Chu, H., Tao, Y., Peng, L., Zhou, L., Liu, L., and Wu, X. (2021). A comparison of triamcinolone acetonide econazole cream and nystatin suspension in treatment of otomycosis. Laryngoscope 131, E1640-E1646.

[51] Osazuwa, F., Osazuwa, E., Osime, C., Igharo, E.A., Imade, P.E., Lofor, P., Momoh, M., Omoregie, R., and Dirisu, J. (2011). Etiologic agents of otitis media in Benin City, Nigeria. North American Journal of Medical Sciences 3, 95-98.

[52] Jia, Y., and Wu, X. (2017). In vitro activity of allicin combined with two antibiotics on intestinal Shigella. Infection International 6, 25-29.

[53] Mozumder;, A., and Hatano, Y. (2003). Charged Particle and Photon Interactions with Matter: Chemical, physicochemical and biological consequences with applications. In CPC Press, pp. $1-844$.

[54] Eltablawy, S.Y and Elhifnawi, H.N. (2010). Effect of garlic oil on attenuation of Pseudomonas aeruginosa. Journal of Radiation Research and Applied Sciences 3, 190-203.

[55] Al-Bayatti, K.K. (2010). The effect of radiation on the antibacterial activity of allicen. AlMustansiriyah Journal for Pharmaceutical Sciences $7,1-6$.
[56] Kwon, J.H., Choi, J.U., and Yoon, H.S. (1989). Sulfur-containing components of gamma-irradiated garlic bulbs. International Journal of Radiation Applications and Instrumentation. Part 34, 969972.

[57] Le Caë, S. (2011). Water radiolysis: Influence of oxide surfaces on $\mathrm{H}_{2}$ production under ionizing radiation. Water 3, 235-253.

[58] Mitchel, R.E.J. (1976). Ionizing radiation damage in Micrococcus radiodurans cell wall: release of polysaccharide. Radiation Research 66, 158-169.

[59] Kwon, J.H., and Yoon, H.S. (1985). Changes in flavor components of garlic resulting from gamma irradiation. Journal of Food Science 50, 1193-1193.

[60] Durairaj, S., Srinivasan, S., and Lakshmanaperumalsamy, P. (2009). In vitro antibacterial activity and stability of garlic extract at different $\mathrm{pH}$ and temperature. Electronic Journal of Biology 5, 5-10.

[61] Li, G., Ma, X., Deng, L., Zhao, X., Wei, Y., Gao, Z., Jia, J., Xu, J., and Sun, C. (2015). Fresh garlic extract enhances the antimicrobial activities of antibiotics on resistant strains in vitro. Jundishapur Journal of Microbiology 8, 1-6.

[62] Cai, Y., Wang, R., Pei, F., and Liang, B.B. (2007). Antibacterial activity of allicin alone and in combination with $\beta$-lactams against Staphylococcus spp. and Pseudomonas aeruginosa. Journal of Antibiotics 60, 335-338.

[63] Irkin, R., and Korukluoglu, M. (2007). Control of Aspergillus niger with garlic, onion and leek extracts. African Journal of Biotechnology 6, 384387.

[64] Aala, F., Kalsom Yusuf, U., and Nulit, R. (2013). Electron microscopy studies of the effects of garlic extract against trichophyton rubrum. Sains Malaysiana 42, 1585-1590.

[65] 65. Gupta, N., and Porter, T.D. (2001). Garlic and garlic-derived compounds inhibit human squalene monooxygenase. Journal of Nutrition 131, 16621667. 